\title{
Permainan Matematika Sudoku di Sekolah Menangah Atas Katolik (SMAK) Warta Bhakti Kefamenanu
}

\author{
Eva Binsasi ${ }^{1)}$ \\ Elinora Naikteas Bano ${ }^{1)}$ \\ Cecilia Novianti Salsinha ${ }^{1)}$ \\ 1) Universitas Timor \\ ceciliasalsinha@gmail.com
}

\begin{abstract}
ABSTRAK: Permainan matematika merupakan salah satu cara untuk membangun minat siswa dan merupakan langkah yang baik agar siswa tidak merasa bosan dalam belajar matematika. Salah satu permainan matematika yang cukup populer saat ini adalah pemainan matematika Sudoku. Puzzle Sudoku identik dengan angka dan cukup rumit jika belum paham aturan permainannya. Tujuan dari teka-teki ini adalah untuk menempatkan angka-angka pada baris dan kolom yang tersedia. Kegiatan ini bertujuan untuk membangkitkan minat belajar matematika siswa dengan metode permainan. Kegiatan ini dilaksanakan selama tiga (3) hari di SMAK Warta Bhakti Kefamenanu kelas X1 IPA 1 dengan jumlah siswa sebanyak 30 orang. Hasil yang dicapai dari kegiatan pengabdian ini adalah rata-rata hasil pre-test siswa sebelum diberikan permainan adalah 48 sedangkan rata-rata hasil post-test siswa setelah diberikan permainan adalah 87.59 . Hal ini menunjukkan bahwa setelah siswa diberikan pemahaman tentang cara bermain Sudoku, hasil yang diperoleh lebih memuaskan dibanding sebelum diberikan pemahaman mengenai permainan ini. Melalui kegiatan ini pula minat belajar matematika siswa dapat dikatakan meningkat.

Kata kunci : Permainan Matematika, Sudoku, Metode Permainan, Belajar Matematika, Minat Belajar Siswa
\end{abstract}

ABSTRACT: Mathematical games is one way to build student interest and it is a good step so students do not feel bored in learning mathematics. One of the most popular math games now is Sudoku. Games Sudoku (Sudoku Puzzles) are identical to numbers and are quite complicated if you don't understand the rules of the game. The purpose of this games is to place the numbers in the available rows and columns. This activity aims to arouse interest in learning mathematics students with the game method.

This activity was held for three (3) days at SMAK Warta Bhakti Kefamenanu class XI IPA 1 with a total of 30 students. The results of this dedication were 48 (average) before the game was given, while the student's post-test results after being given the game were 87.59 (average). This shows that after students are given an understanding of how to play Sudoku, the results obtained are more satisfying than before being given an understanding of this game. Through this activity, student's interest in learning mathematics can be said to increase.

Keywords: Math Games, Sudoku, Game Methods, Learning Mathematics, Interest in Student Learning.

\section{PENDAHULUAN}

Matematika sebagai ilmu hitung sangat bermanfaat bagi kehidupan manusia. Misalnya seorang ibu rumah tangga yang ingin memasak nasi untuk keluarganya yang terdiri dari enam anggota (ayah, ibu dan 4 orang anak). Ibu tersebut harus bisa memprediksi berapa gram atau kilogram beras (bagi masyarakat kampung menggunakan 
ukuran mok) yang harus dimasak agar seluruh anggota keluarga dapat makan dan kenyang. Contoh tersebut merupakan salah satu contoh riil dalam kehidupan sehari-hari yang sangat membutuhkan perhitungan matematis yang mana seorang ibu rumah tangga saja yang entah berpendidikan atau tidak sudah dapat melakukan perhitungan.

Ilustrasi di atas menggambarkan pentingnya belajar matematika. Mata pelajaran matematika merupakan salah satu mata pelajaran yang diajarkan di tingkat Sekolah Dasar (SD) hingga Perguruan Tinggi (PT). Salah satu tantangannya adalah bagaimana seorang pengajar dapat memberikan pemahaman yang baik agar siswa/mahasiswa tersebut dapat mengerti apa yang dijelaskan, sehingga tidak muncul kesan yang negatif saat belajar matematika.

Permainan matematika merupakan salah satu cara untuk membangun minat siswa dan merupakan langkah yang baik agar siswa tidak merasa bosan dalam belajar matematika. Dalam matematika banyak sekali permainan yang dapat digunakan untuk membangitkan minat balajar matematika siswa. Salah satu permainan matematika yang cukup populer saat ini adalah pemainan matematika Sudoku.

Permainan matematika sudoku identik dengan angka dan cukup rumit jika belum paham aturan permainannya. Tujuan dari teka-teki ini adalah untuk menempatkan angkaangka pada baris dan kolom yang tersedia (berbentuk bujursangkar). Mengingat cukup rumitnya permainan ini maka permainan ini lebih cocok diberikan kepada siswa Sekolah Menengah Pertama (SMP) atau Sekolah Menengah Atas (SMA). Seorang siswa akan merasa tertantang jika kotak-kotak dalam baris dan kolom belum terisi semuanya. Dengan permainan sudoku ini seorang siswa selain dilatih untuk menghitung cepat, juga dilatih keterampilannya serta kesabarannya. Akan menjadi kebanggaan tersendiri bila siswa dapat menyelesaikan permainan tersebut.

Bermain sambil belajar adalah salah satu hal yang paling disukai oleh siswa. Melalui permainan matematika sudoku, siswa dengan sendirinya sudah membangun pengetahuannya terkait dengan materi yang berkaitan. Strategi pembelajarannya menjadi berpusat pada siswa, yaitu: 1) siswa sendiri yang berperan aktif, 2) menulis dengan katakata sendiri, 3) belajar kelompok, 4) memecahkan masalah, 5) diskusi/berdebat, 6) mempraktikan keterampilan, 6) melakukan kegiatan penyelidikan (Indrawati, 2009:13). Materi matematika yang berkaitan dengan sudoku yaitu: 1) operasi bilangan (penjumlahan, perkalian dan pembagian) dan himpunan, 2) bangun datar (persegi), 3) barisan dan deret angka, 4) peluang,dan 5) logika. Setiap aspek (materi) memiliki peran dalam permainan Sudoku.

\section{PERMASALAHAN}

Adapun yang menjadi permasalahan pada kegiatan pengabdian ini adalah :

1. Kurangnya minat para siswa dalam pelajaran matematika, khususnya dalam berhitung.

2. Siswa kurang dilatih kemampuannya untuk berhitung cepat, keterampilan dan kesabaran memecahkan masalah matematis pun terkesan sulit bagi siswa. 
3. Siswa kurang memahami apa manfaat dari materi pelajaran matematika tertentu.

\section{METODE PELAKSANAAN}

Metode yang digunakan dalam menjawab permasalahan dalam kegiatan pengabdian ini adalah dengan workshop dengan melalui tahapan-tahapan berikut:

1. Tahap Persiapan

Ada beberapa kegiatan yang dilakukan pada tahapan persiapan yaitu:

a Melakukan koordinasi (pertemuan) dengan pihak sekolah, dalam hal ini Kepala Sekolah SMAK Warta Bakti Kefamenanu dan guru matematika untuk mendiskusikan kegiatan pengabdian;

b Penentuan subjek/peserta pengabdian dengan guru matematika;

c Penentuan waktu pelaksanaan kegiatan bersama dengan guru matematika;

d Mengurus surat ijin pelaksanaan pengabdian dan mempersiapkan alat dan bahan yang digunakan dalam kegiatan pengabdian.

\section{Tahap Pelaksanaan}

Berdasarkan hasil observasi (hasil koordinasi) tanggal 01 Agustus 2018 dengan pihak sekolah, maka kepala sekolah SMAK Warta Bhakti Kefamenanu memberikan ijin untuk dilaksanakannya kegiatan pengabdian di SMAK Warta Bhakti. Berdasarkan hasil tesebut, selanjutnya disepakati bersama waktu pelaksanaan kegiatan pengabdian dengan kepala sekolah dan guru matematika. yaitu tanggal 6-7 Agustus 2018 (lampiran catatan harian). Oleh karena adanya kendala maka kegiatan pengabdian tidak dapat dilaksanakan pada waktu yang telah disepakati sehingga kegiatan tersebut baru terlaksana pada tanggal 12, 13, 15 Oktober 2018 dengan subjek/peserta pengabdian yaitu siswa/siswi kelas dua IPA SMAK Warta Bhakti Kefamenanu.

\section{Kegiatan hari pertama:}

Kegiatan diawali dengan perkenalan singkat dengan peserta kemudian ketua pengabdi menyampaikan maksud dan tujuan kegiatan pengabdian serta memberikan gambaran singkat mengenai permainan matematika sudoku dan kaitannya dengan ilmu yang dipelajari siswa. Setelah kegiatan pembukaan selesai, selanjutnya sebelum memulai dengan permainan puzzle, siswa/siswi diberikan tes awal (pre-test) untuk mengecek kemampuan dasar (berhitung) dan juga pengetahuan siswa mengenai game sudoku. Penyelesaian soal pre-test memakan waktu sekitar 45 menit meski soal yang diberikan terbilang mudah antara lain mengecek kemampuan siswa mengenai bilangan bulat positif, bilangan ganjil dan penyelesaian Sudoku ukuran 3x3. Hal ini diakibatkan oleh kemampuan dasr siswa yang kurang, banyak siswa tidak dapat membedakan mana yang merupakan bilangan ganjil dan genap atau tidak paham batasan bilangan bulat positif. Hasil pre-test dapat dilihat pada Tabel 1. Setelah kegiatan pre-test selesai, para pengabdi mulai memperkenalkan langka-langkah permainan sudoku dan untuk melakukan permainan tersebut, siswa/siswi dibagi dalam beberapa kelompok. Permainan diawali 
dengan bagaimana siswa/siswi mengisi 9 bilangan asli yang pertama pada kotak dengan banyaknya kolom atau baris sama $(\boldsymbol{n}=\mathbf{3})$.

\section{Kegiatan hari kedua:}

Permainan yang dilakukan pada hari pertama adalah perkenalan permainan yang lazim/sering digunakan sehingga siswa/siswi sudah mulai merasa kesulitan saat diberikan kotak $5 x \boldsymbol{5}(\boldsymbol{n}=\mathbf{5})$ yaitu siswa/siswi harus mengisi 25 bilangan asli yang pertama pada kotak berukuran $\mathbf{5} \boldsymbol{x} \mathbf{5}$. Pada kegiatan hari kedua ini, para pengabdi memperkenalkan cara cepat/cara singkat kepada siswa/siswi untuk dapat menyelesiakan permainan puzzle sudoku. Setelah siswa/i memahami langkah-langkah permainan secara cepat dan tepat maka selanjutnya mereka diberikan LKS untuk dikerjakan.

\section{Kegiatan hari ketiga:}

Pada hari ketiga siswa/i diberikan post-test. Kegiatan ini dimaksudkan untuk mengecek pemahaman siswa tentang materi permainan matematika sudoku yang telah dilakukan. Berbeda dengan pre-test, pada post-test selain melihat ketelitian juga dilihat kecepatan dan ketepatan siswa/i dalam menyelesaikan permainan. Untuk itu pengabdi memberikan batas waktu maksimal pengerjaannya adalah 30 menit dengan tingkat kesukaran soal yang meningkat. Pada saat post-test terdapat seorang peserta yang tidak hadir.

\section{PEMBAHASAN}

Peserta yang mengikuti workshop ini sebanyak 30 orang siswa, yang terdiri Berikut ini adalah hasil dari kegiatan pengabdian yang dilakukan kepada 30 orang siswa :

Tabel 1. Rangkuman Hasil Kegiatan

\begin{tabular}{|c|c|c|}
\hline Nomor & Pre-test & Post-test \\
\hline 1 & 40 & 82 \\
\hline 2 & 68 & 100 \\
\hline 3 & 68 & 96 \\
\hline 4 & 48 & 92 \\
\hline 5 & 60 & 84 \\
\hline 6 & 52 & 100 \\
\hline 7 & 44 & 80 \\
\hline 8 & 32 & \\
\hline 9 & 40 & 96 \\
\hline 10 & 30 & 86 \\
\hline$\vdots$ & $\vdots$ & $\vdots$ \\
\hline 28 & 60 & 100 \\
\hline 29 & 40 & 96 \\
\hline
\end{tabular}




\begin{tabular}{|c|c|c|}
30 & 40 & 100 \\
\hline Rata-rata & $\mathbf{4 8}$ & $\mathbf{8 7 . 5 9}$ \\
\hline StandarDeviasi & $\mathbf{1 2 . 2 7}$ & $\mathbf{1 2 . 9 9}$ \\
\hline
\end{tabular}

Hasil pada Tabel 1 di atas merupakan hasil tes sebelum dilakukan permainan dan setelah permainan. Rata-rata hasil pre-test adalah 48.0 yang menunjukkan bahwa secara rata-rata kemampuan dasar berhiutung siswa/i sangat rendah dan mereka belum paham dan tidak dapat melakukan permainan matematika sudoku. Rata-rata hasil post-test adalah 87.59 yang menunjukkan bahwa secara rata-rata siswa/i paham dengan langkah-langkah permainan sudoku sehingga dapat menyelesiakan permainan dengan baik. Hasil pre-test maupun post-test puzzle sudoku disajikan dalam grafik berikut.

\section{GRAFIK HASIL PRE-TEST DAN POST-TEST}

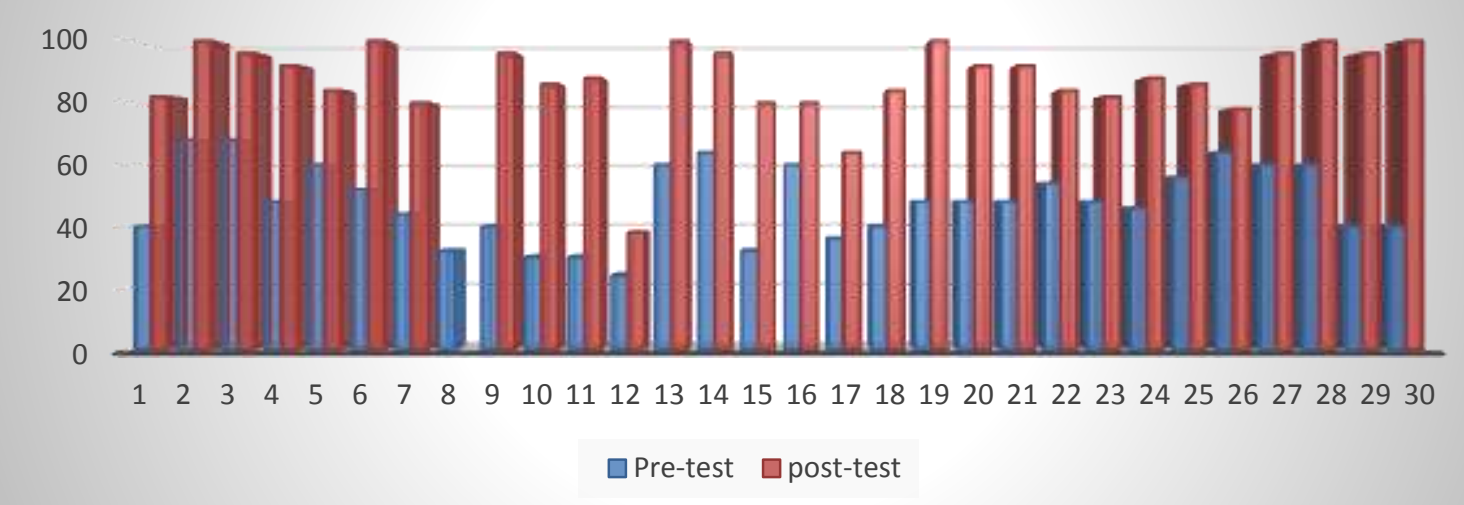

Gambar 1. Grafik Hasil Pre-test dan Post-test

Berdasarkan Gambar 1, terlihat bahwa rata-rata hasil pre-test siswa/i berkisar antara 20 dan 60, sedangkan hasil pos-test berkisar antara 40 dan 100. Grafik di atas menunjukkan bahwa secara rata-rata kemampuan dasar berhitung serta logika berpikir siswa/i SMAK Warta Bhakti kelas 2 IPA Kefamenanu meningkat dan mereka dapat melakukan permainan matematika sudoku dengan baik. Hasil sebaran data hasil tes telihat bahwa data menyebar di sekitar rata-rata tetapi pada post-test terlihat perbedaan nilai minimum dan maksimum yang cukup besar sehingga memberikan variasi yang cukup signifikan dan berdasarkan hasil olahan data terlihat pada Tabel 1 besar nilai standar deviasi untuk post-test 12.99 lebih besar dari nilai standar deviasi untuk hasil pre-test sebesar 12.27. Hal ini menunjukkan bahwa meskipun secara rata-rata hasil post-test lebih baik dari hasil pre-test tetapi sebaran data hasil post-test lebih besar daripada pre-test.

Berdasarkan hasil terlihat bahwa peserta kegiatan pada awalnya belum paham dengan aturan permainan sehingga nilainya rendah, tetapi setelah disampaikan cara cepat untuk dapat mengisi baris dan kolom pada kotak-kotak yang disediakan maka peserta dapat menyelesiakan permainan dengan cepat dan tepat. Puzzle sudoku ini dapat mengajarkan siswa untuk lebih teliti serta sabar dan lebih menyukai matematika. Melalui 
puzzle ini siswa secara tidak sadar sudah memahami konsep dasar aritmatika, logika, peluang, geometri, dan terlebih siswa/i dilatih untuk berhitung secara cepat, tepat serta mampu berpikir kritis dan logis.

\section{KESIMPULAN}

Metode permainan merupakan salah satu cara yang digunakan untuk membuat siswa tertarik untuk belajar matematika. Permainan matematika sudoku merupakan permainan yang rumit dan menantang tetapi menyenagkan. Hasil pre-test dan post-test menunjukkan bahwa secara rata-rata siswa/i tertarik dengan metode permainan matematika sudoku yang diberikan dan siswa/i mampu berhitung dengan cepat dan tepat. Dengan pengalaman bermain matematika sudoku yang sudah dimiliki, siswa/i terus berlatih sehingga dapat meningkatkan kemampuan berhitung secara cepat dan tepat serta dapat meningkatkan logika berpikir siswa/i.

\section{DAFTAR PUSTAKA}

Ahmad, Mufti Aziz. 2008. Sejarah Permainan Sudoku. http://sudokuku.wordpress.com/2008/05/31/sejarah-permainan-sudoku/ diakses pada tanggal 27 Juli 2018

Nuraini, A. 2010. Logika Permainan Sudoku, Program studi teknik informatika sekolah teknik elektro dan informatika institut teknologi Bandung.http://www.informatika.stei.itb.ac.id diakses pada tanggal 18 November 2017.

Khamimah, Nur. 2011. Memanfaatkan Permainan Sudoku untuk Belajar Bilangan Bulat: Sebuah Ide Pembelajaran dalam Pembelajaran Matematika Bermakna. Yogyakarta: tersedia https://nurdinawatikudus.files.wordpress.com/2012/04/diakses pada tanggal 18 November 2017. 